\section{Labial talon cusps: a South American archaeological case in the deciduous dentition and review of a rare trait}

\author{
E. Pomeroy'
}

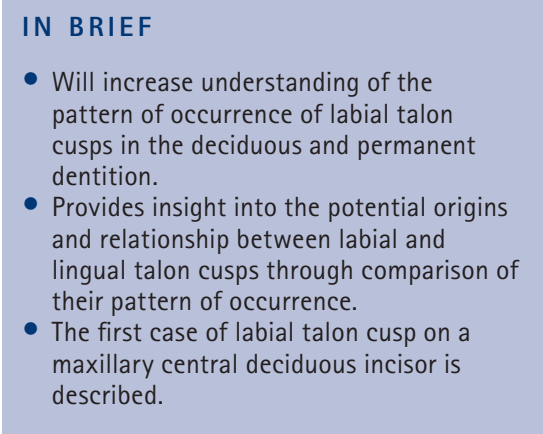
described.

\begin{abstract}
Talon cusps are rarely reported developmental anomalies of the anterior dentition. They occur most commonly on the lingual aspect of the tooth but may also affect the labial aspect, and double (lingual and labial) talon cusps have also been reported. This study presents the first case of a labial talon cusp affecting the maxillary deciduous central incisor to be described in the literature. It was identified in a child skeleton from the archaeological site of Borgatta, north-west Argentina. The aetiology of talon cusps remains uncertain, with a combination of both genetic and environmental factors hypothesised to be involved. As a number of cases of labial talon cusps have now been published, this study presents a survey of cases in the literature to characterise the expression of this trait, and compares it with that of lingual talon cusps. The aim is to offer further insight into the relationship between lingual and labial talon cusps and their aetiologies. Differences between these traits in sex distribution, frequency of maxillary and mandibular cases, and the most commonly affected teeth are demonstrated.
\end{abstract}

\section{INTRODUCTION}

Talon cusps are a rarely reported developmental abnormality of uncertain aetiology which affect the anterior dentition. They form an accessory cusp-like structure comprising an extension of the enamel, dentine and sometimes the pulp cavity of the crown, and may be expressed as a horn-shaped structure standing away from the tooth surface or can form a ridge which is continuous with the surface of the tooth. ${ }^{1}$ The name reflects the resemblance of the most extreme cases to an eagle's talon when viewed from the occlusal edge. ${ }^{2}$ Various other terms have been used to describe this trait including dens evaginatus, supernumerary cusp, horn, hyperplastic cingulum, evaginated odontome, cusped

'Department of Biological Anthropology, University of Cambridge and Honorary Research Fellow, School for Health, University of Bath

Correspondence to: Emma Pomeroy, Leverhulme Centre for Human Evolutionary Studies, Henry Wellcome Building, University of Cambridge, Fitzwilliam Street, Cambridge, CB2 10H

Email:emma.pomeroy@cantab.net

\section{Refereed Paper}

Accepted 6 February 2009

DOI: 10.1038/sj.bdj.2009.168

${ }^{\circledR}$ British Dental Journal 2009; 206: 277-282 cingulum, accessory cusp, and supernumerary lingual tubercle. ${ }^{3}$

Talon cusps vary in their expression in terms of tooth and tooth surface affected, shape and degree of development (Fig. 1). They occur most frequently on the lingual aspect of the anterior teeth, less frequently on the labial surface and occasionally on both..$^{4-6}$ Prevalence rates of lingual talon cusps in modern populations range from $0.06 \%$ to $7.7 \%,{ }^{7}$ with Asian populations showing some of the highest frequencies. However, differences in diagnostic criteria and methods of recruitment between studies may account for rates over $1 \%$ (Fig. 1). ${ }^{6}$

This paper reports a case of a labial (or facial) talon cusp affecting the maxillary deciduous central incisor from an Argentinean archaeological population, and is the first case affecting this tooth to be reported in the literature. Although much less common than the lingual form, a number of cases of labial talon cusps in the deciduous and permanent dentitions are now published but have not been recently synthesised. A review was therefore undertaken to examine the pattern of expression of labial cusps compared with the lingual form, with a view to further our understanding of labial talon cusps and their relationship to the lingual talon cusp in terms of origin and development.

\section{CASE REPORT}

A labial talon cusp was identified on the maxillary left deciduous central incisor of a child's skeleton from the archaeological site of Borgatta (site code SSalCac 16). Located in the Cachi Adentro region of the northern Calchaqui Valley in Salta Province, north-west Argentina, Borgatta is a large residential site in the Andes at approximately 2,500 metres above sea level. It dates to AD1000-1450, a period known as the 'Regional Developments' which predates the incursion of the Inka Empire into the area. The child was interred in a decorated 'Santa Mariana' funerary urn (context 16=23-502-2 locus 1). The urn was buried beneath the floor in a residential structure with the mouth of the vessel protruding above floor level. The child's skeleton was 90\% complete and moderately well preserved. Age at death was estimated at one year ( \pm 4 months) based on dental development. ${ }^{13}$ Sex could not be determined due to the individual's age.

The talon cusp forms a pronounced enamel ridge extending from the 

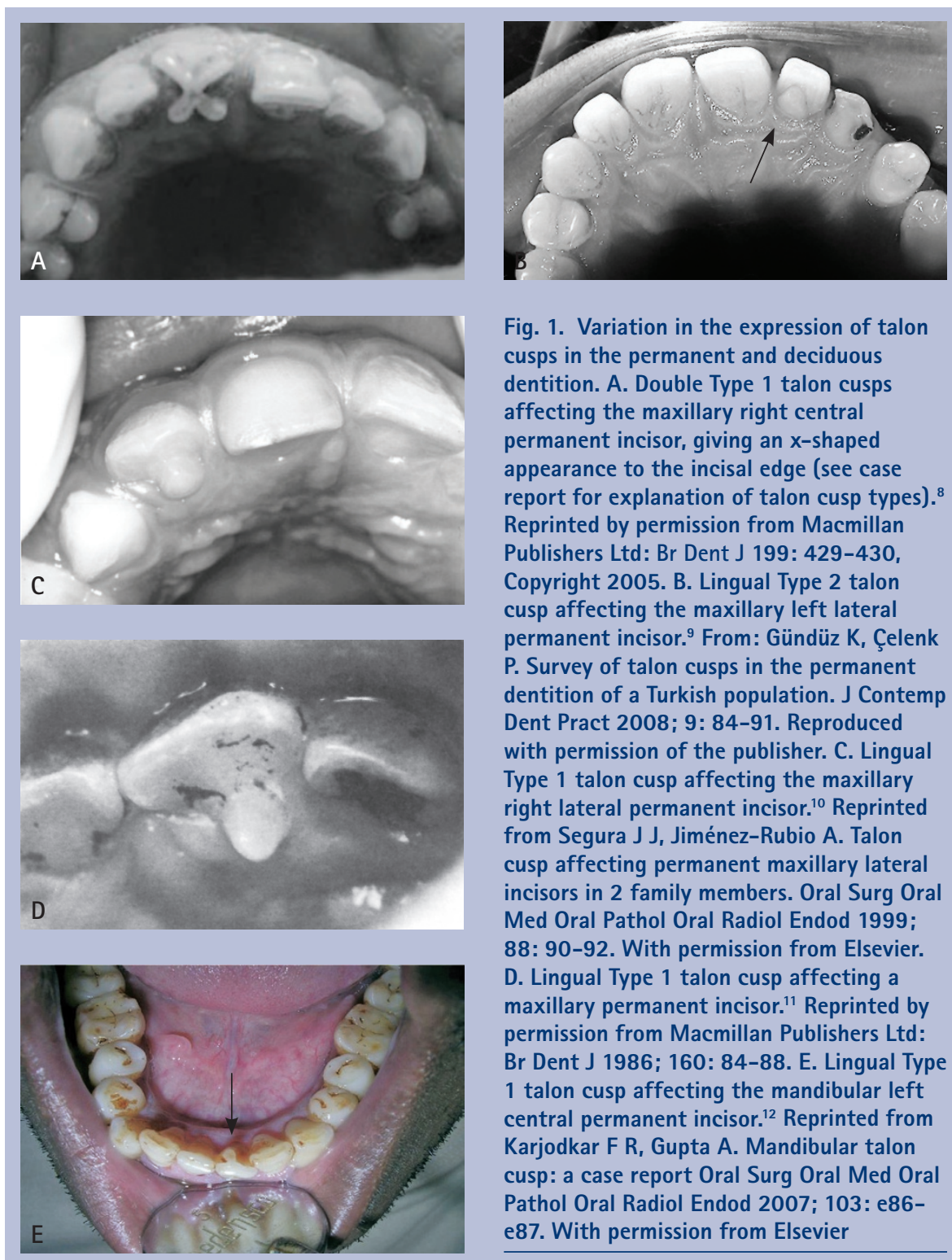

Fig. 1. Variation in the expression of talon cusps in the permanent and deciduous dentition. A. Double Type 1 talon cusps affecting the maxillary right central permanent incisor, giving an $\mathrm{x}$-shaped appearance to the incisal edge (see case report for explanation of talon cusp types). ${ }^{8}$ Reprinted by permission from Macmillan Publishers Ltd: Br Dent J 199: 429-430, Copyright 2005. B. Lingual Type 2 talon cusp affecting the maxillary left lateral permanent incisor. ${ }^{9}$ From: Gündüz K, Çelenk P. Survey of talon cusps in the permanent dentition of a Turkish population. J Contemp Dent Pract 2008; 9: 84-91. Reproduced with permission of the publisher. C. Lingual Type 1 talon cusp affecting the maxillary right lateral permanent incisor. ${ }^{10}$ Reprinted from Segura J J, Jiménez-Rubio A. Talon cusp affecting permanent maxillary lateral incisors in 2 family members. Oral Surg Oral Med Oral Pathol Oral Radiol Endod 1999; 88: 90-92. With permission from Elsevier. D. Lingual Type 1 talon cusp affecting a permission from Macmillan Publishers Ltd: Br Dent J 1986; 160: 84-88. E. Lingual Type 1 talon cusp affecting the mandibular left central permanent incisor. ${ }^{12}$ Reprinted from Karjodkar F R, Gupta A. Mandibular talon cusp: a case report Oral Surg Oral Med Oral Pathol Oral Radiol Endod 2007; 103: e86e87. With permission from Elsevier maxillary permanent incisor. ${ }^{11}$ Reprinted by cemento-enamel junction to the incisor edge (Fig. 2). Viewed from the incisal edge, the tooth has the appearance of a letter ' $\mathrm{T}$ ' with a shortened stem. Hattab et $a l .{ }^{14}$ defined three levels of expression of lingual talon cusps which were adapted for the labial form. ${ }^{15,16}$ The Borgatta case represents the most extreme expression, a Type 1 or 'major' talon cusp, defined as a morphologically welldefined additional cusp projecting from the facial and/or lingual surface of an anterior tooth, which extends at least half the distance from the cementoenamel junction (CEJ) to the incisor edge. Type 2 and 3 talon cusps extend from the cemento-enamel junction to $25-50 \%$ and less than $25 \%$ of the length of the crown respectively. ${ }^{15,16}$ (Note that these definitions differ slightly from the original definitions of Hattab et al., ${ }^{14}$ which defined Type 2 cusps as being at least $1 \mathrm{~mm}$ in length but not extending the full distance to the CEJ, and Type 3 as being an enlarged or prominent cingulum and variations of these traits.)

The mandibular right incisors, maxillary left lateral incisor and the maxillary right central incisor were not preserved, but the mandibular left incisors and maxillary right lateral incisor were unaffected, and no other dental anomalies or pathological conditions were present. It was not possible to assess whether the talon cusp included a pulp extension due to limitations of facilities in the field.

Eleven further child burials were recovered from ceramic vessels in

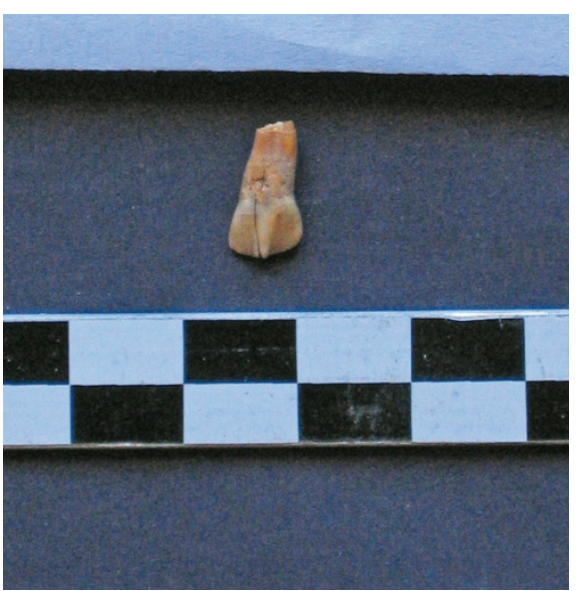

Fig. 2 Maxillary left central deciduous incisor showing a labial talon cusp. Tooth also shows a large post-depositional crack which crosses the incisal edge of the cusp and post-depositional damage to the end of the root

domestic contexts at Borgatta during excavations between 2003 and 2006. All were aged less than six years at death and among the six with at least partial anterior dentitions preserved, none showed any dental anomalies. Individuals over six years of age appear to have been interred in other locations as yet unexcavated, and only a single adult burial (without dentition) was found in this domestic site during these excavations. The prevalence of talon cusps in the permanent dentition of this population could not therefore be assessed.

\section{Labial talon cusps in the literature}

Table 1 summarises the cases of labial talon cusps reported in the dental and archaeological literature. Four other cases of labial talon cusp affecting the deciduous dentition have been reported, all in the maxilla. Three cases affected the lateral incisor of females and were associated with cleft lip and/or palate. ${ }^{4,15}$ One of these cases showed a lingual talon cusp on the same tooth. ${ }^{15}$ The fourth case affected a supernumerary tooth between the left incisors of a male and was associated with a lingual cusp on the same tooth. ${ }^{17}$ The present case is therefore the first to be reported affecting a maxillary deciduous central incisor (Table 1).

The cases reported in the literature may suggest an association between labial talon cusps in the deciduous dentition and cleft lip/palate on the same 
Table 1 Reported cases of labial talon cusps

\begin{tabular}{|c|c|c|c|c|c|c|}
\hline & Population & Sex & Tooth affected ${ }^{a}$ & Reference & Origin & Associated condition(s) \\
\hline \multicolumn{7}{|c|}{ Deciduous Maxillary Teeth } \\
\hline 1 & Swedish & $\mathrm{F}$ & Left i2 & Batra et $a l^{4}$ & Modern & $\begin{array}{l}\text { Right cleft lip and palate and } \\
\text { left partially cleft lip }\end{array}$ \\
\hline 2 & Swedish & $\mathrm{F}$ & Left i2 & Batra et al. ${ }^{4}$ & Modern & Left cleft lip and partial cleft palate \\
\hline 3 & Indian & $\mathrm{F}$ & Right i2 & Jeevarathan et $a l^{15}$ & Modern & Bilateral cleft lip, lingual talon cusp \\
\hline 4 & Turkish & M & $\begin{array}{l}\text { Supernumerary } \\
\text { between left i1 and i2 }\end{array}$ & Siraci et al. ${ }^{17}$ & Modern & Labial and lingual talon cusps \\
\hline 5 & Argentinean & $?$ & Left i1 & Present study & Archaeological & \\
\hline
\end{tabular}

Deciduous Mandibular Teeth - No reports found

Permanent Maxillary Teeth

\begin{tabular}{|c|c|c|c|c|c|c|}
\hline 1 & Japanese & $\mathrm{F}$ & Left I1 & Tsutsumi and Oguchi ${ }^{18}$ & Modern & Incontinentia pigmenti achromians \\
\hline 2 & African American & $\mathrm{F}$ & Right I1 & Jowharji et al. ${ }^{19}$ & Modern & \\
\hline 3 & Irish & $\mathrm{F}$ & Right C & McNamara et al. ${ }^{20}$ & Modern & \\
\hline 4 & Australian & $\mathrm{F}$ & Left I1 & Abbott ${ }^{21}$ & Modern & Lingual and labial talon cusps \\
\hline 5 & Native American (Anasazi) & $\mathrm{F}$ & Left 12 & Turner $^{22}$ & Archaeological & \\
\hline 6 & Native American (Anasazi) & $\mathrm{F}$ & Supernumerary I & Lee et $a l^{23}$ & Modern & \\
\hline 7 & $\begin{array}{l}\text { Native American } \\
\text { (Late Woodland, Illinois) }\end{array}$ & $?$ & Left I1 & Mayes ${ }^{* * 24}$ & Archaeological & \\
\hline 8 & $\begin{array}{l}\text { Native American } \\
\text { (Late Woodland, Illinois) }\end{array}$ & $?$ & Left I1 & Mayes $^{24}$ & Archaeological & \\
\hline 9 & Croatian & M & Left I1 & Glavina and Škrinjarić ${ }^{25}$ & Modern & \\
\hline 10 & Croatian & M & Left I1 & Glavina and Škrinjarićc ${ }^{25}$ & Modern & \\
\hline 11 & Indian & $\mathrm{F}$ & Left I1 & Patil et al. ${ }^{1}$ & Modern & \\
\hline 12 & Malaysian & M & Right 12 & $\mathrm{Ma}^{26}$ & Modern & \\
\hline 13 & Indian & $\mathrm{F}$ & Left I1 & Shashikiran et al. ${ }^{27}$ & Modern & $\begin{array}{l}\text { Double labial talon and lingual } \\
\text { trace talon }\end{array}$ \\
\hline 14 & North American & $\mathrm{F}$ & Right 12 & Dunn ${ }^{28}$ & Modern & $\begin{array}{l}\text { Lingual talon cusps bilaterally } \\
\text { on maxillary } 12 \mathrm{~s}\end{array}$ \\
\hline 15 & British & $\mathrm{F}$ & Right I1 & Sumer and Zengin ${ }^{8}$ & Modern & Labial and lingual talon cusps \\
\hline 16 & British & $\mathrm{F}$ & Right I1 & McKaig and Shaw ${ }^{29}$ & Modern & Labial and lingual talon cusps \\
\hline \multicolumn{7}{|c|}{ Permanent Mandibular Teeth } \\
\hline 1 & German & $?$ & Right I1 & Schulze ${ }^{30}$ & Modern & \\
\hline 2 & Irish & M & Left I1 & McNamara et al. ${ }^{20}$ & Modern & \\
\hline 3 & Native American (Pima) & $\mathrm{F}$ & Left I1, Right I1 & Lee et $a l^{23}$ & Modern & \\
\hline 4 & Native American (Pima) & $\mathrm{F}$ & Left I1 & Lee et $a l^{23}$ & Modern & \\
\hline 5 & Native American (Pima) & M & Left I1, Right II & Lee et $a l^{23}$ & Modern & \\
\hline 6 & Native American (Pima) & M & Left I1, Right I1 & Lee et $a l^{23}$ & Modern & \\
\hline 7 & Native American (Pima) & M & Left I1 & Lee et $a l^{23}$ & Modern & \\
\hline 8 & Native American (Caddo) & M & Left I1, Right I1 & Lee et $a .^{23}$ & Archaeological & \\
\hline 9 & Japanese (Ainu) & $\mathrm{M}$ & Left I1, Right I1 & Lee et $a l^{23}$ & Archaeological & \\
\hline 10 & Spanish & M & Left 12 & $\begin{array}{l}\text { Llena-Puy } \\
\text { and Forner-Navarro }{ }^{31}\end{array}$ & Modern & \\
\hline 11 & Nigerian & M & Left I1 & Oredugba $^{32}$ & Modern & \\
\hline 12 & Chinese & $\mathrm{M}$ & Right fused I1 and I2 & Ekambaram et al. ${ }^{33}$ & Modern & $\begin{array}{l}\text { Double tooth with labial and lingual } \\
\text { talon cusp }\end{array}$ \\
\hline
\end{tabular}


side of the face, although this is tentative due to the small number of cases. Cleft lip and palate are known to be associated with a higher frequency of various dental anomalies including tooth size, number, shape, development and eruption, particularly involving the lateral incisor adjacent to the cleft site. ${ }^{4}$ It could not be determined whether the present case was associated with cleft palate since the palate was not preserved, and cleft lip obviously cannot be assessed in skeletal remains.

Two cases of labial talon cusps in the deciduous dentition occurred with lingual talon cusps. Six of the 28 cases in the permanent dentition were also associated with lingual talon cusps. Whether such double talon cusps represent a separate trait remains unclear.

Comparison of the frequency and distribution of lingual and labial talon cusps indicates a number of differences in their pattern of occurrence. In the permanent dentition labial talon cusps are almost as common in the mandible as in the maxilla (12 cases to 16 respectively). This contrasts with lingual talon cusps where only $6 \%$ of cases affect mandibular teeth. ${ }^{34}$ However, as five of the labial mandibular cases are reported in one study of a single population (Lee et $a l .^{23}$ - albeit a very large study of 1,835 individuals), more data are required to confirm the higher relative frequency of mandibular cases in the labial form than the lingual form. The lack of maxillary cases in that same population might suggest a particular pattern of talon cusps with possible genetic basis, although relatives of the cases reported did not show the trait. $^{23}$ Furthermore, the affected individuals were not thought to be closely related, suggesting any genetic basis is not strong. ${ }^{23}$ Lingual talon cusps in the deciduous dentition appear to be restricted to the maxillary teeth (Lee et $a l .^{3}$ and Mays ${ }^{6}$ jointly report a total of 95 affected individuals), as is the case for the labial form.

Labial talon cusps in the maxillary permanent dentition show a statistically significant female bias $\left(\chi^{2}=4.57, \mathrm{p}=\right.$ 0.033 ), with 11 of the 14 cases where sex is known identified in females. This contrasts with the frequency of lingual talon cusps which are approximately twice as

Table 2 Summary of the pattern of occurrence of labial and lingual talon cusps

\begin{tabular}{l|l|l} 
& Labial talon cusps & Lingual talon cusps \\
\hline Maxillary: mandibular frequency & $\begin{array}{l}\text { P: } 57 \% \text { maxillary } \\
\text { D: } 100 \% \text { maxillary }\end{array}$ & $\begin{array}{l}\text { P: } 94 \% \text { maxillary } \\
\text { D: } 100 \% \text { maxillary }\end{array}$ \\
\hline Male:Female ratio & $\begin{array}{l}\text { P: maxilla 3:11, mandible 9:2 } \\
\text { D: } 1: 3\end{array}$ & PEtD: Approx. $2: 1$ \\
\hline Tooth most commonly affected & $\begin{array}{l}\text { P: Central incisor (75\%) } \\
\text { D: Lateral incisor (60\%) }\end{array}$ & $\begin{array}{l}\text { P: Lateral incisor (55\%) } \\
\text { D: Central incisor (86\%) }\end{array}$ \\
\hline Side affected & Approximately equal & Approximately equal \\
\hline Bilateral cases & $\begin{array}{l}\text { P: maxilla } 0 \%, \text { mandible } 42 \% \\
\text { D: } 0 \%\end{array}$ & $\begin{array}{l}\text { P: } 65 \% \\
\text { D: } 35 \%\end{array}$ \\
\hline P $=$ permanent, $D=$ deciduous. For references see text & \\
\hline
\end{tabular}

common in males as females in both the deciduous and permanent dentitions. ${ }^{3,6,34}$ However, there is some conflicting data regarding the sex bias in the permanent dentition. ${ }^{34}$ It should also be noted that these studies combine mandibular and maxillary lingual talon cusps, although only $6 \%$ of lingual cases affect the mandibular dentition. ${ }^{34}$ In contrast with maxillary cases, mandibular labial talon cusps are more common in males than females (9:2) which is also statistically significant $\left(\chi^{2}=4.45, \mathrm{p}=0.035\right)$.

While lingual talon cusps in the permanent dentition are more common in the lateral incisors (55\% of cases), ${ }^{34} 86 \%$ affect the central incisor in the deciduous dentition. ${ }^{6}$ The pattern is apparently reversed for labial talon cusps. In the permanent dentition, 11 maxillary cases affected the central incisor (69\%), three affected the lateral incisor, one the canine and one a supernumerary tooth. Ten (83\%) of the mandibular cases affected the central incisors, one affected a probable fused central and lateral incisors, and one affected a lateral incisor. In the deciduous maxillary dentition, three cases affected a lateral incisor, one case affected a supernumerary tooth between the incisors, and the case reported in this study affected the central incisor.

Neither labial nor lingual talon cusps show preferential involvement of the left or right side. Nine of the cases in the permanent maxillary dentition affected the left side, six the right side and one a supernumerary tooth. The left side bias is not statistically significant $\left(\chi^{2}=0.57\right.$, $\mathrm{p}=0.44)$ in agreement with the lack of a side bias for lingual talon cusps in the deciduous teeth (side differences for permanent teeth have not been reported). ${ }^{6}$ Among the mandibular cases of labial talon cusps, five affected the left side, two the right side, and five cases were bilateral. This is consistent with the frequency of bilateral lingual talon cusps in the permanent dentition of $65 \%,{ }^{34}$ but contrasts with the absence of bilateral labial talon cusps in the permanent dentition. However, three of the mandibular bilateral labial cases derive from a single population ${ }^{21}$ and again a genetic component may be indicated. None of the labial cases in the deciduous dentition were bilateral, compared with 35\% for lingual cases (calculated from Mays: ${ }^{6}$ Table 1), although sample size for the labial talon cusps was very small.

\section{DISCUSSION}

The aetiology and development of talon cusps remains uncertain. They originate early in tooth development, possibly due to hyperactivity of the dental lamina. ${ }^{14}$ The influence of both genetic and environmental factors (such as damage to the tooth bud) have been suggested but there is little empirical evidence for their relative importance..$^{3,5,6,24}$ Lee et al. ${ }^{3}$ recently suggested that the tendency for hyperactivity of the lamina may be genetically determined with a degree of sex linkage explaining the male bias in lingual talon cusps, while environmental factors may determine the extent of this hyperactivity. Furthermore, they concur with the suggestion that talon cusps represent one end of a spectrum of lamina hyperactivity which includes supernumerary teeth at the other extreme. ${ }^{35}$ Further evidence is needed to support these theories 
and surveys of the occurrence of different variants of the trait may offer additional insight to this problem. However, the current relatively small numbers of reported labial talon cusps must be taken into consideration.

It has been suggested that lingual talon cusps in the deciduous and permanent dentitions should be treated as distinct traits on the basis of the differing frequencies with which lateral and central incisors are affected. ${ }^{6,23}$ The differences in the occurrence of labial and lingual talon cusps presented in this study (summarised in Table 2) might suggest some differences in their aetiology. The female bias in labial maxillary talon cusps may imply a different mode of genetic inheritance from the lingual and maxillary labial forms, and the high proportion of the total mandibular cases coming from a single population $^{23}$ may suggest a somewhat weak genetic basis for this trait since close relatives were unaffected. The absence of bilateral maxillary labial cases in the permanent and deciduous dentitions also appears to differentiate these from the labial mandibular and lingual forms (Table 2).

Archaeological cases have potential to contribute to our understanding of traits which are rare in modern populations, such as talon cusps. The first cases of lingual talon cusps in the deciduous dentition on otherwise normal and double teeth were identified in archaeological populations, ${ }^{5,6,36}$ adding to our knowledge of this trait's expression. Archaeological cases offer additional insight into the aetiology of such traits and regional and temporal variation in their frequency among populations. Recently a talon cusp frequency of $40.8 \%$ in the permanent dentition was reported for an eleventh century Hungarian population, far higher than estimates for modern groups including those currently residing in that region. ${ }^{37}$ This may suggest a particularly strong genetic predisposition or exposure to an environmental stimulus in this population and may warrant further investigation in this and other contemporary nearby populations.

Further examination of the variability of talon cusp expression may also inform our understanding of their aetiology. More frequent examination of the composition of talon cusps, specifically the presence of pulp and dentine, and the relative proportions of the different dental tissues in relation to other features such as size may augment our understanding of the trait's development. As radiography may be unreliable for assessing talon cusp composition, more frequent CT scanning or direct sectioning where possible is necessary. ${ }^{17,38}$

The association of talon cusps with other conditions may afford further insight. Talon cusps may occur in isolation or alongside other dental abnormalities including peg-shaped incisors, dens invaginatus, dens evaginatus of posterior teeth, odontomata, impaction, transposition, and supernumerary or missing teeth (hypodontia). ${ }^{3}$ Recently Lee et $a .^{3}$ demonstrated that $78 \%$ of individuals with lingual talon cusps on a lateral deciduous incisor showed odontogenetic abnormalities in the permanent successor, most commonly supernumerary teeth, while the same was true for only $9 \%$ of cases involving a deciduous central incisor. The present study tentatively suggests some relationship between labial talon cusps in the deciduous dentition and cleft lip/ palate, although treatment for a cleft lip/ palate may increase the chance of the trait being identified, thus introducing a reporting bias. Talon cusps may occasionally be associated with a number of rare genetic syndromes including Mohr syndrome, ${ }^{39}$ Rubinstein-Taybi syndrome, ${ }^{40}$ Sturge-Weber syndrome, ${ }^{41}$ incontinentia pigmenti achromians, ${ }^{18}$ Berardinelli-Siep syndrome ${ }^{42}$ and Ellisvan Creveld syndrome, ${ }^{43}$ but these represent a minority of cases. Although the causation and development of talon cusps remains unclear, the accumulation of additional data on their expression will inform the development and testing of hypotheses in the future.

Research excavations and analysis of materials from Borgatta were funded by the British Academy, the McDonald Institute for Archaeological Research, and Churchill College, through grants to Dr Elizabeth DeMarrais, Department of Archaeology, University of Cambridge. Permission for the research was kindly granted by the Secretary of Culture, Ministry of Education, Salta Province, Argentina. Thanks to Dr Simon Mays for advice on diagnosis. Thank you to two anonymous reviewers for their constructive com- ments, and to Elsevier, Macmillan Publishers and the editor of the Journal of Contemporary Dental Practice for their permission to reproduce the images used in Figure 1.

1. Patil $R$, Singh $S$, Subba Reddy V V. Labial talon cusp on permanent central incisor: a case report. J Indian Soc Pedod Prev Dent 2004; 22: 30-32.

2. Mellor J W, Ripa L W. Talon cusp: a clinically significant anomaly. Oral Surg Oral Med Oral Pathol 1970; 29: 225-228.

3. Lee C-K, King N M, Lo E C-M et al. The relationship between a primary maxillary incisor with a talon cusp and the permanent successor: a study of 57 cases. Int J Paediatr Dent 2007; 17: 178-185.

4. Batra P, Enocson L, Hagberg C. Facial talon cusp in primary maxillary lateral incisor: a report of two unusual cases. Acta Odontol Scand 2006; 64: 74-78.

5. Mays S. An unusual deciduous incisor in a Mediaeval child. J Paleopathol 2003; 15: 159-166.

6. Mays S. Talon cusp in a primary lateral incisor in a Mediaeval child. Int J Paediatr Dent 2005; 15: 67-72.

7. Al-Omari M A O, Hattab F N, Darwazeh A M G, Dummer P M H. Clinical problems associated with unusual cases of talon cusp. Int Endod J 1999; 21: 183-190.

8. Sumer A P, Zengin A Z. An unusual presentation of talon cusp: a case report. Br Dent J 2005; 199: 429-430.

9. Gündüz K, Çelenk P. Survey of talon cusps in the permanent dentition of a Turkish population. J Contemp Dent Pract 2008; 9: 84-91.

10. Segura J J, Jiménez-Rubio A. Talon cusp affecting permanent maxillary lateral incisors in two family members. Oral Surg Oral Med Oral Pathol Oral Radiol Endod 1999; 88: 90-92.

11. Davis $P J$, Brook A H. The presentation of talon cusp: diagnosis, clinical features, associations and possible aetiology. Br Dent J 1986; 160: 84-88.

12. Karjodkar F R, Gupta A. Mandibular talon cusp: a case report. Oral Surg Oral Med Oral Pathol Oral Radiol Endod 2007; 103: e86-e87.

13. Ubelaker D H. Human skeletal remains, 2nd ed. Washington DC: Taraxacum Press, 1989.

14. Hattab F N, Yassin O M, Al Nimri K S. Talon cusp on the permanent dentition associated with other dental anomalies: review of the literature and reports of seven cases. J Dent Child 1996; 63: 368-376.

15. Jeevarathan J, Deepti A, Muthu M S et al. Labial and lingual talon cusps of a primary lateral incisor: a case report. Pediatr Dent 2005; 27: 303-306.

16. Chin Ying S H, Girija V, Fei Y J. Bilateral talon cusp in primary teeth: clinical significance and treatment. J Dent Child 2001; 68: 239-243.

17. Siraci E, Cem Gungor H, Taner B et al. Buccal and palatal talon cusps with pulp extensions on a supernumerary primary tooth. Dentomaxillofac Radiol 2006; 35: 469-472.

18. Tsutsumi T, Oguchi H. Labial talon cusp in a child with incontinentia pigmenti achromians: case report. Pediatr Dent 1991; 13: 236-237.

19. Jowharji N, Noonan R G, Tylka J A. An unusual case of dental anomaly: a 'facial' talon cusp. J Dent Child 1992; 59: 156-158.

20. McNamara T, Haeussler A M, Keane J. Facial talon cusps. Int J Paediatr Dent 1997; 7: 259-262.

21. Abbott PV. Labial and palatal 'talon cusps' on the same tooth. Oral Surg Oral Med Oral Pathol Oral Radiol Endod 1998; 85: 726-730.

22. Turner C G. Another talon cusp: what does it mean? Dent Anthropol 1998; 12: 10-12.

23. Lee C. Burnett S E, Turner C G. Examination of the rare labial talon cusp on human anterior teeth. Dent Anthropol 2003; 16: 81-83.

24. Mayes A T. Labial talon cusp: a case study of preEuropean-contact American Indians. J Am Dent Assoc 2007; 138: 515-518.

25. Glavina D, Škrinjarić T. Labial talon cusp on maxillary central incisors: a rare developmental dental anomaly. Coll Antropol 2005; 29: 227-231.

26. Ma M S. Facial talon cusp: a case report. International Poster Journal of Dentistry and Oral Medicine 2006; 8: 314. 
27. Shashikiran N D, Babaji P, Reddy V V. Double facial and a lingual trace talon cusps: a case report J Indian Soc Pedod Prev Dent 2005; 23: 89-91.

28. Dunn W J. Unusual case of lingual and labial talon cusps. Mil Med 2004; 169: 108-110.

29. McKaig S J, Shaw L. Dens evaginatus on the labial surface of a central incisor: a case report. Dent Update 2001; 28: 210-212.

30. Schulze C. Anomalien und Mißbildungen der menschlichen Zähne. Berlin: Quintessenz Verlags$\mathrm{GmbH}, 1987$.

31. Llena-Puy M C, Forner-Navarro L. An unusual morphological anomaly in an incisor crown. Anterior dens evaginatus. Med Oral Patol Oral Cir Bucal 2005; 10: 13-16.

32. Oredugba FA. Mandibular facial talon cusp: case report. BMC Oral Health 2005; 5: 9.

33. Ekambaram M, Yiu C K Y, King N M. An unusual case of double teeth with facial and lingual talon cusps. Oral Surg Oral Med Oral Pathol Oral Radiol Endod 2008; 105: e63-e67.

34. Dankner $E$, Harari $D$, Rotstein I. Dens evaginatus of anterior teeth: literature and radiographic survey of 15,000 teeth. Oral Surg Oral Med Oral Pathol Oral Radiol Endod 1996; 81: 472-476.

35. Rantanen, AV. Talon cusp. Oral Surg Oral Med Oral Pathol Oral Radiol Endod 1971; 32: 398-400.

36. Sawyer DR, Allison MJ, Pezzia A. Talon cusp: a clinically significant anomaly in a primary incisor from pre-Columbian America. MCVO 1976; 12: 64-66.

37. Mavrodisz K, Rózsa N, Budai M et al. Prevalence of accessory tooth cusps in a contemporary and ancestral Hungarian population. Eur J Orthod 2007; 29: 166-169.

38. Young L, Mass E, Beni L et al. Enamel, dentine and pulp in talon primary maxillary central incisors: a histomorphometric study. Eur Arch Paediatr Dent
2007; 8: 136-140

39. Goldstein E, Medina J L. 1974. Mohr syndrome or oral-facial-digital II: report of two cases. J Am Dent Assoc 1974; 89: 377-82.

40. Gardner D G, Girgis S S. Talon cusps: a dental anomaly in the Rubinstein-Taybi syndrome. Oral Surg Oral Med Oral Pathol Oral Radiol Endod 1979; 47: 519-521.

41. Chen R-J, Chen H-S. Talon cusp in primary dentition. Oral Surg Oral Med Oral Pathol Oral Radiol Endod 1986; 62: 67-72.

42. Solanki M, Patil S S, Baweja D K et al. Talon cusps, macrodontia, and aberrant tooth morphology in Berardinelli-Seip syndrome. Oral Surg Oral Med Oral Pathol Oral Radiol Endod 2008; 105: e41-e47.

43. Hattab F N, Yassin O M, Sasa I S. Oral manifestations of Ellis-van Creveld syndrome: report of two siblings with unusual dental anomalies. J Clin Pediatr Dent 1998; 22: 159-65. 